\title{
Factory and Production Problems to Scientific Management Societies: Legitimacy of the Scientific Management Movement
}

\author{
Fabrika ve Üretim Sorunlarından Bilimsel Yönetim Derneklerine: Bilimse Yönetim Hareketinin \\ Meşruiyet Kazanması
}

\section{Burak Kulli' 10}

\begin{abstract}
This research aims to shed light on the legitimacy phases of the scientific management movement, which stemmed from managerial problems of American railways and heavy manufacturing industries. In the last quarter of the 19th century, managerial problems were started arguing on bulletins, the bulletins of American railways and bulletins of manufacturing industries. This situation pointed to the essentialness of creating a platform for arguing management problems. Within a decade, at first, the American Society for Mechanical Engineering (ASME) transformed into the main platform for the management movement, and soon after, the Taylor Society, named after pioneer of the Scientific Management Movement. From its foundation to its merging under the name of the Society for Advancement of Management, the Taylor Society published dozens of bulletins, under the name of Bulletin of the Taylor Society. The Society became the only platform for the management movement, and hosted national and international management congresses, especially in North America and some European Countries. Therefore, in this research, I evaluated certain important phases of the scientific management movement and brought them into view through investigation support of the management and engineering societies, publications, and national and international congresses.
\end{abstract}

\section{Keywords}

Scientific management, Scientific management society, Taylor society, ASME, Legitimization

\section{Öz}

Bu çalışmada, Amerika'da teknik ve mühendislik uygulamalarının yoğun kullanıldığı demiryolu ağları, ağır sanayiye dayalı endüstri örgütleri gibi yönetim-çalışan ve yönetim-çalışma yeri arasında mesafenin olduğu ve nicelik açısından büyük, aynı zamanda bir arada yönetilmesi zor olan endüstri örgütlerindeki yönetim sorunlarının oluşumuna zemin hazırlayan bilimsel yönetim hareketinin meşruiyet kazanması evrelerinin ortaya konulması amaçlanmıştır. Araştırmada, 19. yüzyılın son çeyreğinde Amerika'da yönetim sorunlarının demiryolu ve sanayi endüstrisi yayın organlarında ele alınmaya başlaması, başta ASME olmak üzere yönetim derneklerinin kurulması ve dernek faaliyetlerinin duyurulması amacıyla ulusal ve uluslararası çapta kongreler düzenlenmesi konuları ele alınmıştır. Bilimsel Yönetim hareketinin bayrak taşıyıcısı olan Taylor Derneği'nin faaliyetlerine derneğin yayın organı Taylor Derneği Bülteni aracılığıyla ulaşılmıştır. Amerika'da endüstri örgütlerinin büyümesi ve çeşitlenmesi ile başlayan yönetim sorunlarının önem kazanmasına ve bilimsel yönetim hareketinin küresel bir boyut kazanmasına kadar geçen süreçte, bilimsel yönetim hareketinin meşruiyet kazanması evreleri ortaya koyulmuştur.

\section{Anahtar Sözcükler}

Bilimsel yönetim, Bilimsel yönetim derneği, Taylor derneği, ASME, Meşruiyet kazanma

1 Corresponding author: Burak Kulli (Res. Asst.), Istanbul University, School of Business, Department of Business, Istanbul, Turkey. E-mail: burak.kulli@istanbul.edu.tr ORCID: 0000-0001-7367-9788

To cite this article: Kulli, B. (2019). Factory and production problems to scientific management societies: Legitimacy of the scientific management movement. Istanbul Management Journal, 87, 159-177. 


\section{Factory and Production Problems to Scientific Management Societies: Legiti- macy of the Scientific Management Movement}

In line with the scientific management movement, it was understood that the problems in industrial organizations stemmed from their managerial habits in the factories, manufacturing process practices and the old way of doing industrial business (Taylor Society 1922). This led managers to focus more on factory and management issues. In the last quarter of the $19^{\text {th }}$ century, managerial and administrative practices for management problems were implemented by wider groups in industrial organizations (Jenks 1960). The meetings, congresses and debates led by names such as H. Towne, H. Metcalfe, F. W. Taylor, M. L. Cooke and F. Gilbreth were influential in the expansion of the scientific management movement (Wren \& Bedian 1994). H. Towne, H. Metcalfe and F. Taylor were the first to publicly announce that management should be a science, with their statements and exemplary managerial practices in the ASME Society, and to contribute to the "legitimacy" of the management movement (Brown 1925; Wren 1994; Berber 2013).

In this study, I discussed the legitimization of the scientific management movement in the United States, through societies, publications and congresses. In this sense, the legitimacy of the American Scientific Management Movement, by adapting to the environment during the institutionalization phase, was discussed on the basis of various environmental factors, such as different societies, publications and congresses.

\section{Aim of the Research and Research Questions}

This study aims to (1) investigate the process of organization of scientific management, starting from the examination of factory and production problems in technical engineering journals (1824-1877), and to reveal the stages of legitimization of scientific management in the United States through content analysis (1886-1936). (2) To determine the important stages and turning points that guide the management science along with the development process of management science in the United States, and to uncover the effects of scientific management in the course of its legitimization. (3) To determine the stages that will form the basis for the studies of the American and European scientific management history and the histographic process, and to establish a ground for further research. In line with the above-mentioned objective, the research questions are as follows:

(1) What were the important events in the process that carry the management movement in the United States from the managerial problems of industrial organizations to the organization of the scientific management movement under the umbrella of a society between 1877 and 1936, and who were the significant figures in this regard? How were these people affected by the conditions of their period and how did they affect the scientific management movement? 
(2) What were the important stages in the institutionalization and the legitimacy of the management movement in the period from the founding of the Society to Promote the Science of Management in 1911 to the founding of the Society for the Advancement of Management in 1936? How did rational myths manifest themselves in the institutionalization of the organization?

\section{Research Methodology}

In this study, the certain phases of the scientific management movements were discussed based on the events, individuals and institutions. The significant events at turning points were investigated by means of acquired key findings. In the collection of study data, bulletins, journals, articles and reports in the society minutes were examined by utilizing the method of document analysis, among the qualitative data analysis methods. The content analysis method was used in the analysis of the study data.

In this context, in addition to current sources in the field of management history and the development of engineering, sources and journals published in the $19^{\text {th }}$ century and in the early $20^{\text {th }}$ century were accessed. The most important of these journals was the Taylor Society Bulletin, which was the publication of the Taylor Society (1914-1934). Of the Journal, 108 issues in its first 18 years were accessed via digital access through the University of Oklahoma. Other issues ( 7 issues in 2 years) were obtained from the Steven Institute of Technology. All the current issues of the journal, which is the main publication platform of the scientific management, were examined, as well as all the activities of the society, related to scientific management and managerial problems. The society meeting minutes, visits, reports and letters in many fascicles of the Journal were also examined by the content analysis method and included in the study.

Attention was paid to the use of primary sources to address the events firsthand by using the Bulletin of the Taylor Society. For example, Henry Towne's manifesto (1886) and Henry Metcalfe's book (1894) are among the primary sources. Secondary sources, however, in particular the works of authors whose studies refer to the primary sources, were used.

\section{Legitimization Phases of the Scientific Management Process}

The managerial problems in the factories and the manufacturing process had first been discussed in technical engineering journals (1824-1877), and had been widely accepted in the American Society of Mechanical Engineers (ASME) (1880-1910), and became known in the national and international arena, thanks to the figures in the Society to Promote the Science of management, under the leadership of Taylor and its 1911-193 Bulletins (Jenks 1960; Wren 1997; Berber 2013). Two research questions came to the fore while addressing the stages of the scientific management process. In 
this sense, important events and persons in the field of management during the period between 1877 and 1936 were examined. Later, between 1911 and 1936, the legitimacy of the management movement, through the society and its publication, was discussed. The important stages of this process were revealed by examining the documents and meeting records. In this sense, the important stages in the development of scientific management were determined by the author of this article as follows (Figure 1):

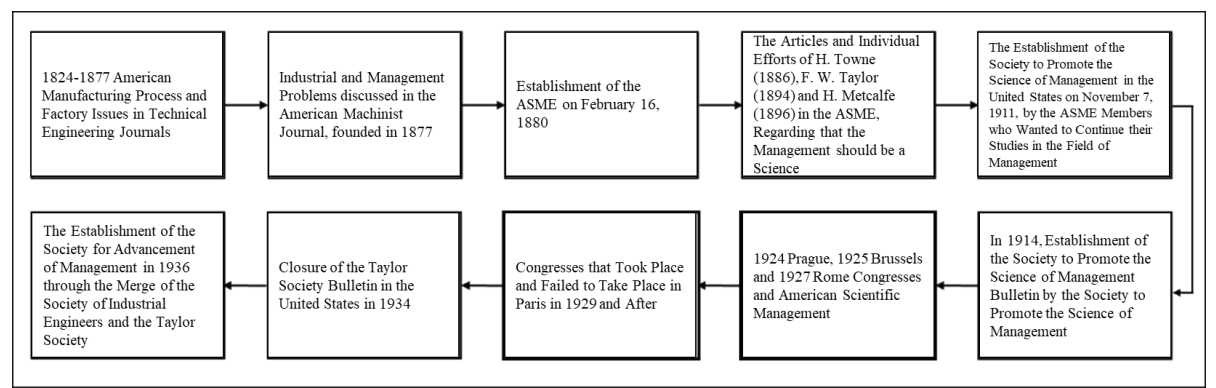

Figure 1. Important Phases in the Development of the Scientific Management Movement

In this sense, the subject headings in the study refer to the events that were revealed as a result of the investigation of the stages addressed within the process presented in Figure 1. Within this course of events, two other events supporting the research were examined. The first of these events was the death of Frederick Winslow Taylor on March 21, 1915. This event led to a number of changes in the Society to Promote the Science of Management. The most important of these, a new belief system within the society was formed after Taylor's death, connecting the members of the society through rational myths based on symbols and normative beliefs (rules and regulations).

In another event, on Wilson's declaration on April 2, 1917, the United States entered the World War I on April 6, 1917. With the news that the United States was going to war, industry organizations began to implement very strict policies on workers and agriculture. The War Industries Board contracted many engineers in the country to work on American war products (Nevins et. 1992). Hence, the society suspended its work for a period of time. After resuming its activities at the end of the war, the Taylor Society started a reorganization in line with the changing circumstances that transformed the structure of industrial organizations in the United States. During this period, the society also tried to be active outside the United States through international congresses.

\section{Discussion on Factory and Manufacturing Process Problems in the United States: Establishment of the American Society of Mechanical Engineers (ASME) \\ The idea of conducting business in American industrial organizations through mechanical equipment and technical schemes determined by managers was adopted by industry organizations (Kotnour and Farr 2005). However, the development process of}


industry in the 1880s led to the problem of the centrality of control and the control of operations in large-scale industries (Brown 1925). There were not any organizations among American industrial organizations that focused on managerial problems and prioritized the development of the manufacturing process, yet (Hutton 1915). The number of engineers in organizations was increasing and engineering was gaining importance, but there was no organization at the local and national level that provided training and created a climate of debate to meet the need for specialization in industrial organizations (Sinclair \& Hull 1980).

The engineers were unable to come together, as there were no engineering unions on a local and national scale (Sinclair 1986). Therefore, engineering societies were needed to institutionalize and regulate engineering activities in the United States. (1) The American Society of Civil Engineers (ASCE) was founded in 1852, and (2) the American Institute of Mining Engineers (AIME) was founded in 1871 (Hutton 1915). The mutual exchange of information between engineers in these societies increased the competence of the societies in their core engineering fields. Yet, these engineering societies had not yet addressed factory problems and manufacturing/ process of manufacturing type engineering problems (Berber 2013).

ASCE and AIME's publications included articles written by mechanical engineers on factory and manufacturing process problems (Sinclair \& Hull 1980). However, resources were quite limited, and a more specialized structure was a necessity to share, discuss and publish works on solving the problems related to mechanical engineering. Indeed, several technical journals met this requirement. The Journal of Franklin Institute, founded in 1826, conducted research and published articles addressing factory and manufacturing process problems. The Journal of Franklin Institute and the American Machinist (1877), Iron Age (1859) and Railway Age (1870) had limited content on factory problems and engineering problems related to the manufacturing process (Hutton 1915).

There was no clear distinction between writers and engineers in the early years in journals in the field of engineering in the United States (Jenks 1960). People were able to work as a writer for the magazine, as well as work as an engineer in industrial organizations (Jenks 1960; Berber 2013). American Machinist, whose editorial team included an engineer manager, started to address factory issues more closely. A proper infrastructure was beginning to form for the mechanical engineers, who were following and working on the problems, through the American Machinist. In line with this development in Mechanical Engineering, Prof. John E. Sweet from the Cornell University Shop Department and John Bailey, one of the founders of the American Machinist, began to look for appropriate ways to establish a society of mechanical engineers. In this sense, a decision was made to hold a meeting to which 
leading mechanical engineers would be invited. The meeting, on January 18, 1880, which Prof. John E. Sweet informed about by letter, was a harbinger of establishing a society of mechanical engineering at the national level (as cited Hutton 1915: 5): “... It having been suggested by several prominent engineers that a national association of mechanical engineers would be desirable, and a meeting for the purpose of taking steps to organize such a society being in order, your presence is hereby requested at the office at American Machinist, 96 Fulton Street, New York...”.

The meeting was held on February 16, 1880, as expected. Thirty engineers attended the meeting, and 18 engineers' letters of thanks were read in the hall. The first chairman, Alexander Holley, and the first secretary, Samuel Weber, were elected at the meeting (Hutton 1915). The name of the society, was designated as the American Society of Mechanical Engineers (ASME), upon the suggestion of Charles W. Copeland (owner of inventions that paved the way for the use of iron in marine and naval).

In his initial statement, chairman Holley stressed that engineers are both managers and the men who engaged in engineering works, hence they must have leadership qualities in the manufacturing process at the factory. He divided the members of the society into two groups in accordance with his emphasized definition. The members were (1) professionals loyal to business practices, and (2) skilled and successful executives on the business side of the industry. The ASME had members not only who focused on technical engineering issues but also had members who focused on management issues. Henry R. Towne (1889-1890) and Frederick W. Taylor (19061907 ) were prominent in the society with their works on scientific management studies (Brown 1925; ASME 2018).

The workers' conditions and external environmental structure of the period had a considerable impact on the emergence of a society, focused towards the factory and production problems, such as the ASME. The United States was facing with a constant wave of labor migration, especially after 1875 (Nevins et. 1992). However, the new immigrant workers were both unskilled and had language barriers (Blake and Moseley, 2010). The manpower, perhaps the most important part of the factory and production process, had to be adapted to working conditions. The organizations in industrial areas such as steelwork mining were growing very rapidly. With this growth, problems were increasing in the factory and production process. Because of the problematic consequences of the changing environment, the idea of set a society to discuss problems and exchange ideas was easily adopted by many.

\section{ASME Members Take the First Steps on the Management Movement}

At a meeting of ASME in 1886, Henry Towne shared his manifesto with the members, which states that the management needs to be a science. His manifesto, titled Engineer 
as an Economist, divided members into managers and engineers, as Chairman Holley mentioned in his first manifesto at the bulletin. However, he also highlighted the scarcity of people with these two characteristics, and emphasized that only those who have these characteristics together can truly achieve success (Berber 2013). Towne, stated that a person with both characteristics would follow operations in all departments of the industrial organizations, either by himself or through employees, and that there would be an improvement in the whole of the organization in this way (Towne 1886). In his manifesto, Towne stressed that science would be the guide for industrial organizations to advance further and improvement (Berber 2013).

Henry Metcalfe was one of those who emphasized the management issues at the ASME. In his book, which he used its summary when presenting his manifesto, Metcalfe has defined (1) science and (2) art, and discussed the concept of management science at the point where science and art mutually converge. According to the Metcalfe, the management could be defined as follows (Metcalfe 1894: 2): "Management is an art... it rests on the application of certain elements to a great diversity of cases which together constitute what could be called the science of management".

Henry Metcalfe, who interpreted the concept of art in the $19^{\text {th }}$ century's the United States for the science of management, expressed the art here as all the methods, knowledge and rules in performing a work. In this sense, management art is the expression and transmission of goals and thoughts to others through skills, competencies and experiences. Management science, however, can be expressed as the systematic advancement of all knowledge in the field of management, which is uncovered and analyzed through experiences and research in whole.

At the end of the $19^{\text {th }}$ century, the idea of management science, which was accelerated by the papers of Towne and Metcalfe, and which began to be widely accepted with the influence of Taylor's studies, was adopted by members such as James M. Dodge, Henry Gantt, Frank B. Gilbreth, Carl G. Barth and Morris L. Cooke, who would make their names in the field of management (Brown 1925; Wren 1997; Berber 2013). The ASME's meetings become starting point for the following congresses, publications, studies and discussions in the field of management.

By the 1910s, all the engineering sciences in the United States were on a rapid rise (Kotnour \& Farr 2005; Sinclair 1986). The ASME had to choose between management and engineering to avoid lagging behind the trend in ever-expanding engineering fields. Hence, the ASME decided it was best for the Society to turn to the purely engineering field. The opportunity to study and discuss management issues was very limited in the ASME in the early 1910 (Brown 1925). However, as stated in early and informal meetings, some members of the ASME had a desire to gather under the roof of the new society, the scientific management society. 


\section{The Supporters of the Scientific Management Movement Establishes the Society to Promote the Science of Management after Failure to Get Help from the ASME}

In the case of the American Eastern Rail Road Company's increased transportation fees beginning at the end of 1911 and lasted in early 1912, Louis Brandies the lawyer, who was among the pioneers of the scientific management, stated that it would be beneficial to utilize the practices of the scientific management. Efficiency studies led by Frederick Taylor in this case gave good results. With this case, the scientific management movement has become widely followed by the public, and turn into legitimate in society (Hutton 1915; Taylor Society 1922; Brown 1925).

After the ASME's decision to support pure engineering works, which had already carried out relatively less management and purer engineering works, since 1907, Frank Gilberth stated that it would be a great shame not to continue Taylor's work (Taylor Society 1924; Taylor Society 1930). There are some interesting and important reasons why Gilbreth supported Taylor. We can list these reasons as follows (Nadwordy 1957):

(1) Taylor and Gilbreth met at ASME in 1907 for the first time. Gilbreth was heavily influenced by Taylor's 1903 dated book, the Workshop Management. Taylor, had also stopped doing paid counseling during those years. However, Taylor brought together the names of those who worked with his methods in relation to the scientific management movement, which he regarded himself as the protector and leader of the movement. They were working as "management experts" and providing consultancy to companies. Gilbreth wanted to be one of Taylor's management professionals. However, the group, which called itself the "Taylorists", did not want to include a new management expert among themselves.

(2) Frank Gilbreth focused on his work in industrial management in 1912. However, he began to provide consultancy services to firms in the field of scientific management. This caused Taylorists to take a hostile stance on Gilbreth. Taylor's management science experts considered Gilbreth's action as a condition that may pose a threat to economic competition in the society. This argument continued after Taylor's death. F. Gilbreth mentioned about that Taylorists' time studies were weaker compared to his own motion studies. Indeed, Sanford Thompson (chairman of the Taylor Society in 1932) emphasized again that Gilbreth's and Taylor's team ultimately served the same purpose. What these two names had in common in their works was the just "efficiency."

Frank Gilbreth continued to provide consulting services on the scientific management, using the name of the Taylor Society, despite the occasional conflicts between them. These were the most important reasons underlying the insistent request for the foundation of the Society to Promote the Science of Management in 1910 and the effort to change the name of the society to the Taylor Society in 1915. 
On November 11, 1910, the group of scientific management experts, such as M. Cooke, R. Kent, C. Lauer and W. Lewis, held meetings at the New York Athletic Club (Taylor Society 1922; Brown 1925). At this meeting, it was decided to establish an organization in order to discuss management problems and promote scientific management. The group, which continued to hold regular meetings for over a year, officially met for the first time on November 7, 1911 at the Hotel Astar in New York, and took the name Society to Promote the Science of Management (Taylor Society 1914; Taylor Society 1922). Management science gained a formal identity for the first time through the Society to Promote the Science of Management.

\section{With the Initiatives of the Society to Promote the Science of Management in the United States in 1914, the Scientific Management Movement Now has a Publication}

Since most of the members of the society were also the members of the ASME, most of the meetings of the society took place in New York, where the ASME also had its headquarters. In Philadelphia, a place with intense industrial organizations, the followers of the scientific management movement were gathering together and holding meetings. From its very first official meeting, the society aimed to gather members and announce its works. The members of the society, who benefited from Taylor's recognition, were aiming to provide consulting services within the framework of scientific management practices to wider circles (Nadworny 1957). Three years after the Society to Promote the Science of Management gained its formal and institutional identity, it decided at the 11th meeting of the Philadelphia Engineers Club on November 24, 1914 to have a publication (Taylor Society 1914: 2):

"Is this society a mechanism or an organism?... A mechanism is a whole made up of parts which function together because of some external force... An organism is a whole made up of parts... Society [Taylor Society] like this must be an organism to live and justify its existence... Every member of the society must contribute his shares. All need not contribute alike, but each must be give according to his opportunity..."

The publication, named as the Bulletin of the Society to Promote the Science of Management, published its first issue in December 1914. In this issue, 61 members of the society (as of 1914) were introduced, including the honorary member F.W. Taylor in particular. Taylor and his followers were the most influential figures in the functioning of the society. They were very fond of the idea of issuing a bulletin to disseminate their actions within the society and other circles, and to disseminate and discuss the scientific management practices they were developing. The chairman Person, who was one of the closest names to Taylor, called for active participation of members for the society's functioning, and stated the following in his allegorical article in the first issue of the society (Taylor Society 1914: 3): 
In the bulletin, schedules of all meetings, congresses, important developments in the field of management, overseas membership meetings, and manifestos were published for 20 years and 115 issues, starting with its first issue (1914) until its final issue (1934). The society was first consisted of the people who gathered around the scientific management philosophy that Taylor had theorized in his work in "Shop Management" in 1903 dated and discussed the rest of his life. However, almost all of its early members were also either an industrial organization stakeholder or senior executive. At the same time, the members of the society were "scientific management professionals who have long worked in the field and have a wide range of knowledge of the subject" as Taylor puts it, and they were providing management consulting services to the US government and private companies (Nadworny 1957). In this sense, the bulletin on scientific management served as a platform to promote them in wider circles.

Some important events addressed by the Bulletins of the Society to Promote the Science of Management are as follows (Table 1):

Table 1

Some Important Events addressed by the Journal of the Society to Promote the Science of Management

On November 11, 1910, the Society to Promote the Science of Management was established.
On December 4,1915, The Journal of the Society to Promote the Science of Management began publication.
On March 21, 1915, upon Taylor's death, the name of the society changed to the Taylor Society.
In December 1922, the manifesto, titled "What is the Taylor Society?" published in the bulletin.
An important step towards internationalization of scientific management: November 1924, meeting of the
directors of the society with the French and British members.
The first International Management Congress held in Prague in 1924.
The second International Management Congress held in Brussels in 1925.
The third International Management Congress held in Rome in 1927.
Although the fourth International Management Congress was held in Paris in 1929, it failed to attract the
expected attention.
1934 Bulletin of the Taylor Society ceased publication.

All the phases of the Society to Promote the Science of Management have been instrumental in the expansion of the scientific management movement, and having national and international followers.

\section{The Death of the "Pioneer of the Management Science": The Society to Promote the Science of Management Changes its Name to the Taylor Society}

F.W. Taylor, who spent 12 years in different positions at the Midvale Factory (18781890), had the opportunity to perform many implementations related to the factory, the manufacturing process and management problems. Afterwards, between 1890 and 1900, he provided consultancy services to industrial organizations. In 1886, while 
still at Midvale, he was impressed by Towne's manifesto, called the Engineer as an Economist. He was the head of the ASME in 1905-1906 (Brown 1925). His books, written in 1903, 1904 and 1911, made crucial contributions in the development of the scientific Mmnagement in the Railway Case in 1911-1912 and the Watertown Inquiry in 1911 (Taylor Society 1922; Berber 2013). He gave lectures on management courses at Harvard University from 1909 to 1914. Taylor was memorialized as a pioneer of the scientific management in 1921 by H. Towne, one of the architects of the idea that management should be a science (Taylor Society 1916). F. W. Taylor died on March 21, 1915. The Society to Promote the Science of Management held a memorial service for him at the state university on November 22, 1915.

After Taylor's Death, the Bulletin of the Society to Promote the Science of Management was renamed as The Bulletin of the Taylor Society. The reasons for the change were published in the bulletin, together with H. Hathaway's grounds, the society's chief financial officer. The society's this new name would bring with it a number of revisions along with memberships (Taylor Society 1916). Accordingly, the name of the society was changed to Taylor Society, because:

1. The society was founded by Taylor's followers and developed through Taylor's work,

2. The first name that comes to mind when thinking of scientific management is Taylor and this will instill a sense of trust,

3. of the need for determining a clearer competence and ranking for members,

4. and, to support the members through the principles and ethical codes created by Taylor.

In consideration of these statements, the group, named the Taylor Society, aimed to increase the effectiveness on the society by using the name of F.W. Taylor, the pioneer of Scientific Management, in order to disseminate its works to a wider audience and to accelerate the development of the society by attracting qualified members. On the other hand, the society has been desired to be active not only in the United States, but also outside the United States, internationally. In this way, it was aimed to allow members of the society to use scientific management practices in order to advise various countries' governments and private and public enterprises in these countries on the efficiency-oriented system of scientific management (Lauer 2010).

After the death of Taylor, the honorary chairman of the society and the most important name recognized both in the United States and worldwide, the work on the philosophy of scientific management in the society was largely abandoned. However, the promotion of scientific management practices using the name of the Taylor Society and the increased the number of members of the society made a significant contribution to the society. Nevertheless, the society suspended its works temporarily for a time due to the war. 


\section{On April 2, 1917, the US Enters the WWI: Reorganization at the Taylor Society in 1919}

The efforts to the society to gain qualified members resulted well, and the number of members in the society rose to 110 until April 2, 1917, when the United States entered the WWI. However, throughout the war period, the Taylor Society's activities were suspended, and more than $50 \%$ of its members took part in war-related organizations in the United States (Jenks 1960; Taylor Society 1922). After the US's success in the war, they were invited to be consultants by many industry organizations throughout the United States, most of whom worked under the supervision of the War Industries Board during the war.

Immediately after the armistice in 1918, the society's members in Washington returned to society's activities. This move aimed to undertake more important works in the society and to create wider public service opportunities in the reorganization. In this sense, the decision was made to establish a central office to manage the budget. On April 1, 1919, the head office of the society was established at the engineering societies building in New York city. The society would reach branches around a head office with the new organization. Thus, both more members and more industry organizations would benefit from scientific management practices and contribute in the field of scientific management. In addition, another factor in moving the society to New York could have been that it acted in cooperation with the other societies. However, New York city was a good choice for the internationalization of the society's activities, especially during the period between the two wars.

Within 2 years after this reorganization and centralization of the society, the number of members of the society has increased to 802 (Brown 1925; Taylor Society 1922). In addition, with this post-war move, the society made both its own name and scientific management more recognizable internationally. Thanks to the society, more members of industrial organizations were able to benefit from the practices of scientific management theory. In addition, members were able to exchange information with each other, as well as receive counseling support from the society. This process and the society's desire to expand to the world led to the need to redefine the Taylor Society.

\section{Manifesto of the Chairman Person: "What is the Taylor Society?"}

As the chairman of the society, Person wrote a paper in 1922, 3 years after the reorganization of the society, describing the Taylor Society's functions in 5 provisions. The general functions of the Taylor society, according to Person are as follows (Taylor Society 1922):

1) Taylor society is an organization composed of managers, management engineers and other stakeholders who want to support and understand the managerial principles and the methods of management in order to meet industrial demands. 
2) Taylor Society is a society that draws attention to administrative and managerial problems, solves specific managerial problems with scientific methods, and exerts efforts to develop the habit of thinking logically.

3) The methods used by the Taylor Society in supporting managerial problems are as follows:

National meetings held every three months (paper presentations, committee meetings, discussions on managerial issues)

Monthly meetings of local units (paper presentations, committee meetings, discussions on managerial issues)

Bimonthly published bulletins (significant papers, meeting minutes, other special contributions)

The consulting and information service in New York was a service where members discussed managerial problems and received support from those with similar problems in the past.

4) The Taylor Society seeks appropriate basic logic and applicable methods for its members to implement the best management and administrative practices.

5) The Taylor Society seeks and deals with the best ideas and methods from whatever and wherever the source is. The expectation of the society from its members is that they accept management as a science and provide support in this regard.

In his work, Person the president of the Taylor Society mentioned minor services of the society, such as education, consultation and information service, as well as the general functions of the society.

In particular, consultancy services were provided to the members of the society at no additional cost. However, this service was merely a superficial consultation that was not detailed. It was also stated that the only source of income for the society was membership fees and a limited number of bulletin memberships. However, members of the society, especially those at the top of the society (those who are close to Taylor and/or close to Taylorists) provide income by advertising through the society and providing consultancy services in many private industry organizations. This also shows the existence of a structure that contradicts the values of the society (Taylor Society 1922).

Many associations established during the same period as the Taylor Society have disappeared over the past 10 years. The Taylor Society was successful in bringing together the members in well-defined training and service programs. The society also guided members to become a professional manager rather than a trade expert. In this sense, the Taylor Society was able to discuss what its members can put forward for the development of scientific management thinking in the society (Brown 1925; Taylor Society 1922). However, it should be noted that senior members were the consultants with good marketing skills, who have managed to expand their activities into the international arena. 


\section{International Management Congresses}

After the end of the First World War in 1918, the extent of international interactions had increased further. Some of those who benefited from this interaction were those within the management movement. Between the two world wars he organized 8 international management congresses from 1924 to 1935. The first two congresses were quite important for the American-based scientific management movement. The idea of scientific management, pioneered by F.W. Taylor and supported by the Taylor Society and many American industrial and engineering societies, had a repercussion in Europe. However, scientific management practices, which were widely applied in the US, were adopted more by developing countries in the eastern Europe and looking for an opportunity, rather than the UK, France and Germany, where governments had higher sanction power over industrial organizations and were successful in the industry in Europe (Berber 2016). In this sense, the 1924 Prague and 1925 Brussels congresses had been a turning point for the American-based scientific management movement.

The first international congress of management was held in Prague on June 21-24, 1924 in line with the idea of management, which was gaining traction rapidly. The following American management and engineering societies, notably the Taylor Society, attended the congress, which included 40 American representatives such as:

- Taylor Society

- American Engineering Council

- American Institute of Electrical Engineers

- American Management Association

- American Society of Mechanical Engineering

- National Association of Cost Accountants

- National Association of Office Managers

- Society of Industrial Engineers

At the congress, which was open to all participants dealing with management issues, 17 papers were presented, addressing management issues in different areas (for full list of calls: Taylor Society 1924: 100). Prague Congress made history in terms of management science in two ways:

(1) The polarization due to the Scientific Management Movement (Taylorism) emerging in the United States, and the Management Process Movement (Fayolism) emerging in Europe was evident (Berber 2016). However, it was necessary to wait until the next congress to resolve this issue.

(2) International members of the American-based scientific management movement met for the first time on a formal ground. Especially in scientific management 
practices, developing countries such as Czechoslovakia, Romania, Russia and Poland were found to be strict followers of the American system (Taylor Society 1924; Berber 2013).

After the Prague Congress, Person had the opportunity to meet with French and British members in Paris and London. The members of the Taylor Society, hosted by M.C. Freminville, one of the representatives of the scientific management movement in Paris, France, held discussions on scientific management, the international exchange of information, the exchange of publications, and the international visits of the society. Since the trip to London was in August (calling holiday time by English members), some of the members of the society were interviewed individually. It would not be wrong to state here that a country that is strong in industries and whose approach to workers is different, such as the UK, was less interested in the management movement. Yet, mutual exchange of ideas was made in these meetings for the expansion of the Taylor Society in Europe (Taylor Society 1924).

The second international congress of management was held in Brussels on 1418 November 1925. The congress, held under the auspices of the king of Belgium, confronted M. C. Freminville, pioneer of the American scientific management movement in Europe, and Henri Fayol, pioneer of the management process in Europe (Taylor Society 1925). The 84-year-old Henri Fayol and Freminville (proponents of two different movements of management thought) argued that, in fact, scientific management and management process movements were shaped by the common system of ideas, but they differed from each other in practice (Taylor Society 1925). Freminville's statement at the end of Fayol and Freminville's argument was written by M. Rene De Valliére and M. Paul Devinat in the Bulletin of the Taylor Society as follows (Taylor Society 1925: 240):

"...As far as then years ago, he has been asking me for the analogies and differences between his idea and those of Taylor... He [Fayol] told me that he believed Taylor had denied the unity of command and that he wished that, speaking before him [Taylor]... where unity did not exist, and the management did not fulfill its duty... [Fayol] stated that the differences was not in the principles involved but only in the means used and the field of action ... He considers that I have made possible the alliance of Fayolism and Taylorism and that this is an epoch-making event!..."

Henri Fayol's Management Process approach and Taylor's Scientific Management approach were the confrontation of two paradigms, similar to that of two different methods trying to reach a single conclusion, as in the confrontation between Gilbreth and Taylor. These two methods aimed to achieve a resulting effectiveness and efficiency by approaching the problems of industry organizations from different angles. 
The 1927 Congress of Rome took place during the presidency of Mussolini, who ruled Italy with a repressive regime starting in 1925. Participants from Europe, Asia and the United States took part in the congress with 2,000 soldiers on duty. It is stated that the Congress of Rome drew attention in the bulletin of the society. However, the fact that the congress took place under a more repressive regime probably caused some of the participants to not to attend, leading to failure to attract the expected interest.

Together with the Paris Congress of 1929, the Congress of Amsterdam and London were also held. However, these congresses have lagged behind other management movements such as the Bedaux method and the Management Process approach, which have developed in Europe (Wren 1997). At these congresses, the Taylor Society fell far behind in reaching large-scale industrial organizations in Europe and failed to receive the attention it expected. Although the Taylor Society was considering to organize a congress in Nazi Germany as its last and perhaps the greatest, chance, according to the circumstances, it failed to do so in the period just before the WWII (Kipping 1997).

Thus and hence, the Taylor Society, which failed to get the expected support from the primary industrial countries in Europe, again focused on its work within the United States. However, it faced a lot of problems in the post-Great Depression era (1929-1939).

\section{Celebrations of $50^{\text {th }}$ Year of ASME's Foundation as Presented in the Bulletin}

The ASME Society, where the foundations of the Taylor Society were laid, celebrated its $50^{\text {th }}$ anniversary at its offices in New York and Washington between April 5 and 8, 1930. There was also intense participation of the Taylor Society at the ASME's founding events. H. Towne and F. W. Taylor's initiatives in the movement of management as a science were addressed.

The Taylor Society had opened its head office in 1919, in the building where ASME was founded. On the separation of mechanical engineering and management, the speakers stated the following (Taylor Society 1930: 62):

"For nearly twenty-five years A.S.M.E. remained practically the only influence in the development of a science of management. Then expansion of the content of mechanical engineering compelled that Society about 1907 to begin to give relatively increasing attention to pure engineering and less to management, and the latter field soon became the concern of the specialized Taylor Society organized by a small group, particularly interested in management, within A.S.M.E. "'

As can be understood based on this conversation, the ASME and the Taylor Society had a large number of common members because of their natures. In addition, the Taylor Society held numerous common members with the ASME until it merged with the Society of Industrial Engineers in 1936. 


\section{Taylor Society and American Society of Industrial Engineers Merge: Society for Advancement of Management}

The Taylor Society bulletin, the publication of the Taylor Society, ended its publishing life by issuing its last bulletin in 1934. The society's publication reported important activities, practices and developments in the field of scientific management and published articles on important practices for 20 years between 1914 and 1934. In addition, it has also participated in many activities to gain qualified members and support members (Jenks 1960). The society introduced scientific management to the whole America and then to the whole world through his system of thought and practice. Engineering activities are also very important in the recognition of this management movement.

In the Post-Taylor period, the society moved away from studies on the philosophy of scientific management and attempted to promote scientific management practices first in the US and then in Europe, which changed the society's quest. In particular, the image of the platform for discussion of scientific management, which is intended to be established with the Taylor Society Bulletin, has changed its place to be a platform for marketing of scientific management practices.

The idea of promoting scientific management to the Europe with the international management congresses and showing the practices did not receive support from countries such as Britain, France, and Germany, which prioritize the industries, and the incoming support remained only at an individual level. In addition, the society has found many followers in the Eastern Europe and Soviets, called secondary industries. However, the long-term implementation of the practices could not be ensured given the situation between these countries and the two wars. However, it failed to attract the expected attention at the congress held in Paris in 1929, and the congress was held with mostly the participation of French members of the society (Kipping 1997). Subsequent meetings of the society were also held in Europe through the individual relations and the efforts of the members of the society.

Industrial Engineering also became increasingly important after the WWI. Upon this, industrial engineers also established a society, called the Society of Industrial Engineering (Kotnour \& Farr 2005). The society, in which Gilbreth was also among its pioneers of ideas, has been a professional tool for the practice of group management techniques (Jenks 1960). The Taylor Society merged with the Society of Industrial Engineers, which dealt with industrial and managerial problems, and continued its activities under the roof of the Society for Advancement of Management.

With this newly established society, attention was paid more to the efficiency and effectiveness concepts in the scientific management thinking, instead of scientific management practices. This has led to the legitimacy and acceptance of the American scientific management movement in the United States and now in the world as a 
management practice, rather than as a way of thinking, like the similar ones in Europe, such as the French Management Process and the British Bedaux system.

Grant Support: The author received no financial support for this work.

\section{References}

ASME (2018). Presidents, Choronological List of ASME Presidents, https://community.asme.org/ board_of_governors/w/wiki/6387.asme-presidents.aspx, Erişim Tarihi: 18.01.2019

Astley, W. G., \& Van De Ven, A. H. (1983). Central perspectives and debates in organization theory. Administrative Science Quarterly, 245-273.

Berber, A. (2013). Klasik yönetim düşüncesi: geleneksel ve klasik paradigmalarla klasik ve neoklasik örgüt teorileri. İstanbul: Alfa Yayınları.

Berber, A. (2016). 100 yıl öncesine bir yolculuk: "Genel ve endüstriyel yönetim” ve Fransa'da fayolizmtaylorizm kutuplaşması. Istanbul University Journal of the School of Business, 45, 118-132.

Blake, A. M., \& Moseley, J. L. (2010). One hundred years after the principles of scientific management: frederick taylor's life and impact on the field of human performance technology. Performance Improvement, 49(4), 27-34.

Brown, P. S. (1925). The work and aims of the taylor society. The Annals of the American Academy of Political and Social Science, 119(1), 134-139.

Hutton, F. R. (1915). A history of the american society of mechanical engineers from 1880 to 1915. The Society.

Jenks, L. H. (1960). Early phases of the management movement. Administrative Science Quarterly, 421-447.

Kipping, M. (1997). Consultancies, unstitutions and the diffusion of taylorism in Britain, Germany and France, 1920s to 1950s. Business History, 39(4), 67-83.

Kotnour, T., \& Farr, J. V. (2005). Engineering management: Past, present, and future. Engineering Management Journal, 17(1), 15-26.

Lauer Schachter, H. (2010). The role played by frederick taylor in the rise of the academic management fields. Journal of Management History, 16(4), 437-448.

Metcalfe, H. (1894). The Cost of Manufactures and the Administration of Workshops, Public and Private. J Wiley.

Nevins, A., Commager, H. S., ve Morris, J. B. (1992). A Pocket History of the United States (Vol. 9023). Simon and Schuster.

Nadworny, M. J. (1957). Frederick Taylor and Frank Gilbreth: Competition in scientific management. Business History Review, 31(1), 23-34.

Sinclair, B., \& Hull, J. P. (1980). A Centennial History of the American Society of Mechanical Engineers, 1880-1980. Published for the American Society of Mechanical Engineers by University of Toronto Press.

Sinclair, B. (1986). Local history and national culture: notions on engineering professionalism In America. Technology and Culture, 27(4), 683-693.

Taylor Society (1914). Bulletin of The Society to Promote the Science of Management. December, Vol:1, No 1: 1-5. 
Taylor Society (1915). Bulletin of The Society to Promote the Science of Management. November, Vol:1, No 6: 1-36.

Taylor Society (1916). Bulletin of The Society to Promote the Science of Management. January, Vol:2, No 1: 1-20.

Taylor Society (1922). Bulletin of The Society to Promote the Science of Management. December, Vol:7, No 6: 209-246.

Taylor Society (1924). Bulletin of The Society to Promote the Science of Management. June, Vol:9, No 3: 97-156.

Taylor Society (1925). Bulletin of The Society to Promote the Science of Management. December, Vol:10, No 6: 238-281.

Taylor Society (1930). Bulletin of The Society to Promote the Science of Management. December, Vol:15, No 2: 62-136.

Towne, H. R. (1986, August). The Engineer as an Economist. In Academy of Management Proceedings (Vol. 1986, No. 1, Pp. 3-4). Briarcliff Manor, NY 10510: Academy of Management.

Wren, D. A., and Bedeian, A. G. (1994). The Evolution of Management Thought. 6. Ed. John Wiley. Wren, D. A. (1997). The Evolution of Management Thought. 7. Ed. John Wiley. 
